\title{
TRUDNOŚCI I WYZWANIA DZIALAŃ Z ZAKRESU PROMOCJI ZDROWIA WŚRÓD OSÓB BEZDOMNYCH
}

\begin{abstract}
Abstrakt. Bezdomność jest tego rodzaju kryzysem w życiu człowieka, który bardzo silnie wpływa na działania jednostki we wszystkich wymiarach zdrowia, na jej codzienne wybory i hierarchię potrzeb. Walka o przetrwanie i konieczność zaspokojenia podstawowych potrzeb wyklucza koncentrowanie się na własnym zdrowiu i dbanie o jego dobry stan, a wręcz nierzadko sprzyja jego pogorszeniu. Problem stanu zdrowia osób bezdomnych i przyjęty przez nie styl życia najdobitniej pokazuje, że promocja zdrowia nie może ograniczyć się tylko do chwytliwych medialnych haseł czy prostych wskazówek, jak zdrowo żyć. Wymaga uwzględnienia szeregu różnych zmiennych, a nade wszystko całego kontekstu społecznego.

Celem przygotowanego artykułu jest próba odpowiedzi na pytanie o możliwość i skuteczność działań z zakresu promocji zdrowia wśród grup wykluczonych na przykładzie osób w kryzysie bezdomności. Na podstawie badań własnych prowadzonych wśród podopiecznych schronisk dla bezdomnych w Łodzi (wywiady swobodne z ustrukturalizowaną listą pytań) i pracowników tychże placówek (wywiady swobodne pogłębione) autor stara się odpowiedzieć na pytanie, jaki jest stan wiedzy bezdomnych na temat prozdrowotnego stylu życia, jakie zachowania związane ze zdrowiem są charakterystyczne dla tej grupy, ale nade wszystko jakie czynniki wpływają na styl życia, w tym wybory zdrowotne, i kształtują stan zdrowia osób zepchniętych na margines społeczny.
\end{abstract}

Słowa kluczowe: bezdomni, promocja zdrowia, styl życia, zdrowie.

\section{Kilka słów wprowadzenia na temat idei promocji zdrowia}

Współczesne koncepcje związane z poszukiwaniem nowych rozwiązań w kwestii poprawy stanu zdrowia społeczeństw kładą większy nacisk na czynniki kontrolowane przez jednostkę, w tym przede wszystkim na styl życia. Jest to

* dr n. społ., Pracownia Patologii Społecznych w Zakładzie Medycyny Zapobiegawczej, Uniwersytet Medyczny w Łodzi, 90-419 Łódź, ul. Żeligowskiego 7/9, e-mail: katarzyna.pawlak@, umed.lodz.pl 
wyraz procesu przechodzenia od „ery medycznej” do „postmedycznej”. Idea utożsamiająca dobrą opiekę medyczną z wysokim poziomem zdrowia społeczeństw przestała być możliwa do obrony, zwłaszcza w świetle badań epidemiologicznych, udowadniających wyższość czynników środowiskowych i elementów stylu życia nad rozwojem medycyny w kształtowaniu zdrowia jednostek. To nowe spojrzenie pojawiło się i zyskało szerszy rozgłos dzięki raportowi LaLonde’a. Koncepcja pól przyjęta we wspomnianym dokumencie z 1974 roku wskazuje wyraźnie cztery czynniki mające znaczenie dla stanu zdrowia jednostki (LaL onde 1981), jednocześnie podkreślając, że nie są one sobie równorzędne, a więc ich siła oddziaływania na zdrowie człowieka jest różna.

Aktualne oszacowania udziału poszczególnych czynników w polu zdrowia przypisują największą rolę stylom życia, odpowiedzialnym za kształtowanie go w około $50 \%$, następnie czynnikom środowiskowym (25-35\%), czynnikom biologicznym (10-15\%) i opiece zdrowotnej (10-20\%) (Sadowski 1994: 19).

Raport LaLonde'a, choć podkreślił znaczenie środowiska dla ryzyka zdrowotnego, a także czynników behawioralnych w determinowaniu zdrowia (styl życia), to interpretował je zupełnie niezależnie, nie szukając wspólnego mianownika. „Destrukcyjne style życia (destructive lifestyle habits) zostały potraktowane jako dobrowolnie wybrane ryzyko (self-imposed risks) i wskazano je [...] jako czynnik determinujący zdrowie, oddziałujący jednak obok zagrożeń środowiskowych" (Skrzypek, Marzec 2018: 234). Rozdzielenie środowiskowych i behawioralnych uwarunkowań zdrowia nierzadko skutkuje podejściem, w którym za zły stan zdrowia obwinia się chorego (i jego niewłaściwe wybory) z pominięciem przyczyn o charakterze społecznym, ekonomicznym, psychicznym itp., które stoją za tymi wyborami. Zapomina się, że prozdrowotne style życia opierają się na wyborach jednostek, ale wyborów jednostka dokonuje tylko z dostępnych jej opcji, te zaś uzależnione są od jej szans życiowych i całego kontekstu społecznego, w którym jest zanurzona (Cockerham, Ritchey 1997).

Nawiązująca do raportu LaLonde'a Karta Ottawska z 1986 roku wydaje się w swoich zapisach uwzględniać tezy związane ze społeczną genezą zdrowia i podkreślać ich znaczenie w budowaniu koncepcji promocji zdrowia. Problem jednak polega na tym, że te zapisy nie są w wystarczający sposób uwzględniane i stosowane we współczesnych koncepcjach promocji zdrowia. Konsekwencją takiego stanu rzeczy jest obniżona efektywność działań prowadzonych w jej ramach (Cianciara 2011). Karta Ottawska wprowadziła do promocji zdrowia tzw. podejście siedliskowe (Grossmann, Scala 1997), które podkreśla konieczność aktywizacji jednostek i grup lokalnych w „miejscach” (rozumianych jako społeczność lub organizacja), w których spędzają najwięcej czasu, tzw. siedliskach. Działania w siedliskach mają z jednej strony utrudniać zachowania, które są szkodliwe dla zdrowia, i sprzyjać tym, które niosą potencjał zdrowotny, jednocześnie podkreślając znaczenie współpracy i aktywności całej społeczności wokół problemów 
zdrowotnych. Podejście siedliskowe uwypukla zarówno potrzebę szeroko pojętej wielopoziomowej edukacji, jak i konieczność przeobrażeń warunków życia i działania systemu społecznego. Jednakże, jak zauważa Puchalski,

o ile założenia siedliskowej promocji zdrowia mogą wydawać się spójne, o tyle brakuje teorii zachowań zdrowotnych - obejmującej całą ich różnorodność i wskazującej na liczne ich uwarunkowania - która byłaby odpowiednia dla jej praktycznych potrzeb. Sama promocja zdrowia wydaje się obecnie rozwijać bardziej w kierunku polityki zdrowotnej i teorii zarządzania zmianą społeczną niż teorii zachowań (stylów życia) związanych ze zdrowiem. Natomiast dyscypliny tradycyjnie badające takie zachowania, choć próbują przekraczać istniejące pomiędzy nimi granice, częściej zamykają się we własnych wąskich opcjach (Puchalski 2008: 211).

Nauki medyczne pomijają zupełnie psychologiczne i społeczne aspekty zachowań jednostek w obszarze zdrowia, koncentrując się tylko na posiadanej przez nie wiedzy lub ewentualnie odwołując się do przyczyn natury ekonomicznej. Psychologia skupia się na działaniach racjonalnych jednostki, która, pozbawiona emocji, nieustannie kalkuluje swoje postępowanie w kategoriach zysków i strat, dążąc do realizowania wyznaczonych sobie celów zdrowotnych. Wreszcie socjologia więcej uwagi poświęca zmiennym makrostrukturalnym o charakterze demograficznym niż społecznym (Puchalski 2008).

Współczesne koncepcje promocji zdrowia wymagają ponownej refleksji, a nade wszystko odrzucenia wąskiego analizowania zachowań zdrowotnych w kategoriach posiadanej wiedzy i statusu ekonomicznego jednostek i otwarcia się na szeroki kontekst społeczny.

Celem przygotowanego artykułu jest pokazanie trudności w zakresie promocji zdrowia i próba odpowiedzi na pytanie o możliwość oraz skuteczność tych działań wśród grup wykluczonych na przykładzie osób bezdomnych. Na podstawie badań własnych, prowadzonych wśród bezdomnych z Łodzi, autor stara się odpowiedzieć na pytanie, jaki jest stan wiedzy osób bezdomnych na temat prozdrowotnego stylu życia, jakie zachowania związane ze zdrowiem są charakterystyczne dla tej grupy, ale nade wszystko jakie czynniki wpływają na styl życia, w tym wybory zdrowotne, i kształtują stan zdrowia osób zepchniętych na margines społeczny.

\section{Material i metody}

Prezentowane w niniejszym artykule dane pochodzą z projektu badawczego „Ekskluzja i marginalizacja społeczna. Socjomedyczne aspekty bezdomności kobiet i mężczyzn z województwa łódzkiego"1. Na podstawie ogólnopolskiego

${ }^{1}$ Projekt badawczy realizowany w latach 2014-2016 w Uniwersytecie Medycznym w Łodzi w Zakładzie Patologii Społecznych. Zadanie badawcze nr 502--03/6-029-08/502-64-070, finansowane przez UM w Łodzi. 
badania liczby osób bezdomnych szacuje się, że w całym województwie łódzkim bezdomność dotyczy prawie 1800 osób, z czego niemalże połowa egzystuje na terenie miasta Łódź (MOPS 2019). Te same badania wskazują, że ponad $70 \%$ łódzkich bezdomnych korzysta z pomocy instytucji takich jak schroniska lub noclegownie. Na terenie Łodzi funkcjonuje schronisko dla bezdomnych mężczyzn dysponujące 170 miejscami oraz noclegownia dla 100 potrzebujących, prowadzone przez Towarzystwo Pomocy im. św. Brata Alberta. Bezdomne kobiety mogą skorzystać ze schroniska kierowanego przez wspomniane Towarzystwo (60 miejsc) lub miejskiego schroniska dla kobiet (62 miejsca). Placówki przyjmują również kobiety ze starszymi dziećmi (ŁUW 2019).

Na pierwszym etapie badań terenowych zrealizowano 100 wywiadów swobodnych z ustrukturalizowaną listą pytań wśród bezdomnych obu płci przebywających w schroniskach prowadzonych przez Towarzystwo Pomocy im. św. Brata Alberta na terenie Łodzi oraz w miejskim schronisku dla kobiet. Podstawowym narzędziem badawczym był autorski kwestionariusz ankiety składający się z 55 pytań oraz dołączone do niego testy psychologiczne: Kwestionariusz Nadziei na Sukces i Skala Samooceny Rosenberga. Ze względu na dużą rotację podopiecznych, zwłaszcza w męskich schroniskach, oraz niechęć bezdomnych do wzięcia udziału w badaniu (duża liczba odmów) zastosowano dobór oparty na dostępności badanych. Warunkiem przystąpienia respondenta do badania było korzystanie w trakcie realizowania projektu z pomocy jednej z czterech placówek, na terenie których prowadzone były badania.

$\mathrm{Na}$ drugim etapie zrealizowano 12 wywiadów swobodnych pogłębionych z pracownikami schronisk. Respondentów wybierano na podstawie doboru celowego. Pracownicy byli dobierani, po pierwsze, ze względu na różnorodne funkcje pełnione w placówkach - w celu zebrania jak najpełniejszego obrazu zjawiska bezdomności. Wywiady przeprowadzono zarówno z osobami zajmującymi funkcje kierownicze, jak i opiekunami bezdomnych oraz osobami pracującymi w obszarze szeroko rozumianej opieki medycznej: pielęgniarka, psycholog, psychoterapeuta. Drugim kryterium był co najmniej pięcioletni staż pracy, by móc uzyskać informacje zmian z perspektywy czasowej. Prezentowane w niniejszym artykule dane oparte są na materiale zebranym na obu etapach badań.

\section{Wybrane zachowania osób bezdomnych związane ze zdrowiem}

Karta Ottawska definiuje promocję zdrowia jako „proces umożliwiający ludziom zwiększenie kontroli nad własnym zdrowiem oraz jego poprawę. Kontrola nad własnym zdrowiem oznacza tu przede wszystkim kontrolę nad czynnikami determinującymi zdrowie" (Ostrowska 1999: 165). Istotne w idei promocji zdrowia jest zwiększanie kompetencji jej odbiorców w dostrzeganiu problemów zdrowotnych i radzeniu sobie z nimi, m.in. poprzez kształtowanie odpowiedniej 
motywacji, świadomości, umiejętności czy wiedzy. Jednakże założenia tej idei są znacznie szersze. W odróżnieniu od oddziaływań profilaktycznych, opierających się na teorii racjonalnego wyboru, promocja zdrowia wskazuje, że sama racjonalna kalkulacja zysków i strat z przedstawionych alternatyw to za mało. Podkreśla znaczenie społecznych, strukturalnych i kulturowych determinantów ludzkich wyborów. Możliwości, z których jednostka dokonuje wyboru, są ograniczone takimi czynnikami jak: sytuacja życiowa, miejsce w strukturze społecznej, wartości wpojone w procesie socjalizacji, tradycja i wiele innych (Ostrowska 1999). Wydaje się więc zasadne dla dalszych rozważań krótko scharakteryzować wybrane zachowania osób bezdomnych związane ze zdrowiem, które będą stanowiły punkt wyjścia do analizy czynników wpływających na dokonywane w tym zakresie wybory. Zaprezentowane dane pochodzą ze 100 wywiadów swobodnych z ustrukturalizowaną listą pytań zrealizowanych wśród bezdomnych przebywających w łódzkich schroniskach.

Tabela 1. Wybrane zachowania bezdomnych związane ze zdrowiem

\begin{tabular}{|l|c|}
\hline \multicolumn{1}{|c|}{$\begin{array}{c}\text { Wybrane zachowania związane } \\
\text { ze zdrowiem }\end{array}$} & $\begin{array}{c}\text { Odsetek osób, których dane } \\
\text { zachowanie dotyczy } \\
\text { Dane \% N = 100 }\end{array}$ \\
\hline Palenie tytoniu & 88 \\
\hline Brak jakiejkolwiek aktywności fizycznej & 56 \\
\hline Bardzo częsty, niemalże permanentny stres & 55 \\
\hline Czas na regenerację - mniej niż osiem godzin & 55 \\
\hline Brak regularności spożywania posiłków & 54 \\
\hline Niezdrowe odżywianie się & 49 \\
\hline Spożywanie alkoholu & 49 \\
\hline Najczęstszy sposób odreagowania stresu: tytoń & 38 \\
\hline Liczba posiłków - mniej niż trzy na dobę & 22 \\
\hline
\end{tabular}

Źródło: opracowanie własne.

Zdecydowana większość badanych bezdomnych paliła wyroby tytoniowe (88\%). Prawie $2 / 3$ palących sięgało po $11-20$ papierosów dziennie. Zaledwie $7 \%$ pytanych nigdy nie paliło, a 5\% rzuciło palenie. Wśród palących dominowały osoby, które tkwią w nałogu 10 lat i dłużej (89\%). O sile nałogu decyduje nie tylko czas jego trwania. Palący bezdomni przyznawali, że bardzo szybko po przebudzeniu muszą zapalić pierwszego papierosa: 40\% z nich czyniło to w ciągu pierwszych 30 minut, a 34\% nawet do 5 minut. Ponad połowa palących deklarowała również, że nie potrafi zrezygnować z wyrobów tytoniowych w miejscach publicznych. Podobny odsetek sięgał po papierosa nawet w okresie choroby. 
Ponad połowa pytanych (56\%) przyznała, że nie podejmuje żadnej aktywności fizycznej. W grupie tej dominowały kobiety. Tylko niespełna co dziesiąta $\mathrm{z}$ nich deklarowała aktywność ruchową. Przeważający odsetek respondentek przyznał się do całkowicie biernego trybu życia. Wśród bezdomnych mężczyzn taka postawa cechowała ponad $1 / 4$ badanych. Wśród usprawiedliwień braku aktywności dominowały dwa - stan zdrowia (ponad $1 / 3$ wskazań) oraz brak potrzeby (również blisko $1 / 3$ wskazań). Pierwszy z przytoczonych argumentów był najczęściej wykorzystywany przez bezdomnych mężczyzn. Zły stan zdrowia, związany m.in. z przebytymi operacjami, różnego rodzaju obecnymi schorzeniami, słabym wzrokiem, a nawet brakiem sił, jako przyczyna uniemożliwiająca podejmowanie aktywności fizycznej został wskazany przez ośmiu na dziesięciu niećwiczących mężczyzn. Większość kobiet prowadzących bierny tryb życia deklarowała, że nie widzi potrzeby podejmowania aktywności ruchowej (ponad 1/3), w drugiej zaś kolejności wymieniła stan swojego zdrowia (co piąta niećwicząca kobieta). Dominujący wśród bezdomnych bierny tryb życia potwierdziły także deklaracje dotyczące sposobu spędzania wolnego czasu. Podopieczni schronisk najczęściej czytali książki lub gazety, spali lub oglądali telewizję.

Osoby bezdomne często narażone są na czynniki stresogenne. Zaledwie 5\% pytanych zadeklarowało, że w ogóle nie odczuwa stresu. Z drugiej strony, ponad połowa $(55 \%)$ z nich określiła częstotliwość doświadczania sytuacji stresowych jako częste lub bardzo częste. Do najczęstszych czynników stresogennych bez względu na płeć należą: sytuacja życiowa, w jakiej znaleźli się badani, brak pracy i mieszkania oraz konieczność przebywania w schronisku. Mężczyźni deklarowali również brak kontaktu z dziećmi, lęk przed przyszłością oraz chorobę czy niepełnosprawność. Kobiety z kolei wymieniały problemy z innymi podopiecznymi schroniska.

Rytm życia w schronisku w pewien sposób ułatwia zachowanie odpowiedniej dawki snu w ciągu doby oraz liczby posiłków. Przebywanie w schronisku i związane z tym bezpieczne miejsce noclegu powoduje, że zdecydowana większość bezdomnych śpi powyżej pięciu godzin na dobę. Z drugiej jednak strony 55\% pytanych przeznacza mniej niż osiem godzin na regenerację.

Schronisko nie tylko zapewnia bezdomnym bezpieczne miejsce do spania, ale także m.in. możliwość skorzystania z posiłków. Tym samym osoby przebywające w takiej instytucji nie muszą martwić się o zdobywanie żywności ani o częstotliwość jej spożywania. Mimo to $22 \%$ badanych jadło mniej niż trzy posiłki na dobę.

Właściwy sposób odżywiania nie jest związany tylko z liczbą przyjmowanych pokarmów, ale także $\mathrm{z}$ regularnością oraz rodzajem zjadanych produktów. Ponad połowa respondentów (54\%) zadeklarowała brak stałych godzin posiłków. $\mathrm{W}$ tej grupie dominowały przede wszystkim kobiety. Mniej niż $1 / 5 \mathrm{z}$ nich przyznała, że jada o regularnych porach. W przypadku mężczyzn tendencja była odwrotna - niemal $3 / 4$ z nich zadeklarowało stałe godziny posiłków.

W wypadku osób bezdomnych przebywających w schronisku kwestia spożywanych produktów w dużej mierze nie jest zależna od nich samych, a od ośrodka, 
w którym mieszkają. Tylko 16\% badanych przyznało, że je bardzo zdrowo. Ponad $1 / 3$ pytanych twierdziła, że stara się zdrowo odżywiać, jednocześnie zdaje sobie sprawę, że nie zawsze się to udaje. $42 \%$ respondentów z pełną świadomością deklarowało, że odżywia się niezdrowo. Jednocześnie $31 \%$ z nich podkreślało, że czyni tak nie z własnego wyboru. Ich sposób odżywiania był bowiem uzależniony od tego, co otrzymają w schronisku. Pozostałe $11 \%$ pytanych przyznało, że z całą świadomością dokonuje niewłaściwych wyborów żywieniowych. Natomiast 7\% badanych w ogóle nie zastanawiało się nad tym, co je. Większość bezdomnych pytanych o ewentualne modyfikacje sposobu odżywiania zwracała uwagę przede wszystkim na produkty, które jedliby, gdyby sytuacja materialna im na to pozwalała. Respondenci deklarowali chęć zmiany swojej diety poprzez wzbogacenie jej głównie o owoce (64\%), warzywa (56\%), mięso (52\%) i ryby (31\%). Kobiety najczęściej przyznawały, że gdyby mogły, jadłyby częściej owoce i warzywa. Mężczyźni zaś zdecydowanie chętniej wybierali mięso i nabiał, a w porównaniu do kobiet - także częściej deklarowali apetyt na ryby, słodycze czy białe pieczywo.

$51 \%$ badanych zadeklarowało abstynencję alkoholową. Biorąc pod uwagę wypowiedzi opiekunów schronisk, a także opierając się na innych badaniach przeprowadzonych wśród bezdomnych (Piekut-Brodzka 2013), wydaje się, że uzyskany wynik jest zawyżony. Grupa osób bezdomnych przebywająca w placówkach jest dosyć szczególna pod względem omawianego problemu ze względu na obowiązujący w schroniskach całkowity zakaz spożywania alkoholu, co powoduje, że badani mogli niechętnie przyznawać się do picia lub zaniżać rzeczywistą częstotliwość sięgania po alkohol. Wydaje się, że taka tendencja dotyczyła szczególnie kobiet, w wypadku których aż 3/4 negowało nawet okazjonalne picie. Wpływ na otrzymane wyniki mógł mieć także charakterystyczny w procesie uzależnienia mechanizm zaprzeczania, który powoduje, że osoba uzależniona neguje występowanie u siebie objawów.

Wśród osób używających alkoholu przeważali ci, którzy deklarują spożywanie 1-2 porcji (trochę ponad 2/5) lub 3-4 porcji (prawie 1/3) na raz w okresie picia. Więcej niż co 10 osoba przyznała się do wypijania 5-6 porcji i niemalże tyle samo - nawet $10 \mathrm{i}$ więcej. Charakterystyczny jest również rodzaj spożywanego alkoholu. Najczęściej są to wybory spirytusowe, kupowane z „niepewnego źródła”, bez akcyzy, a więc wątpliwej jakości.

\section{Czynniki wpływające na zmianę zachowań w obszarze zdrowia osób bezdomnych}

Podstawą prowadzenia działań z zakresu promocji zdrowia jest obecnie dostarczenie wiedzy jednostkom charakteryzującym się deficytem informacji i wyposażenie ich w tzw. kompetencje społeczne. Zakładanie jednak, że nabycie przez bezdomnych wiedzy z zakresu prozdrowotnego stylu życia przełoży się na 
praktykę działania, jest zbyt dużym uproszczeniem. Wybory życiowe, także te należące do obszaru zdrowia, zależą od wielu czynników. Wiedza ma oczywiście znaczenie, ale jest tylko jedną z licznych zmiennych wpływających na motywację do działania i wiarę w swoje możliwości.

Kluczowe są także zmienne demograficzne, sytuacja materialna, przebieg procesu socjalizacyjnego i utrwalone w nim wzory zachowania, model rodziny, w której wzrastała jednostka, posiadana sieć wsparcia społecznego, sposób spostrzegania siebie oraz swojego miejsca w życiu społecznym, kondycja zdrowotna, a nawet czas pozostawania bezdomnym (Rys. 1). Wszystkie te elementy, „zanurzone" w makrospołeczne przemiany oraz uwarunkowania kulturowe, oddziaływają na siebie i są ze sobą połączone. Tym samym tylko analiza wszystkich tych czynników pozwala stworzyć całościowy obraz szans na zmiany zachowań bezdomnych w obszarze zdrowia oraz określić sposób i skuteczność działań promujących zdrowy styl życia wśród tej grupy społecznej.

Osoby bezdomne mają często świadomość, na czym polega zdrowy tryb życia. Obraz bezdomnego, który ma jedynie podstawowe lub wręcz niepełne podstawowe wykształcenie i brak elementarnej wiedzy, także w zakresie prozdrowotnym, jest uproszczony, fałszywy i oparty na stereotypach. Wśród respondentów z przytaczanego badania autorskiego $32 \%$ posiadało wykształcenie zawodowe, $29 \%$ średnie, a 6\% wyższe. Wyniki te potwierdzają również dane zebrane podczas ostatniego nocnego liczenia bezdomnych (MRiPS 2019). W samej Łodzi na 651 pytanych 197 zadeklarowało wykształcenie zawodowe, 119 średnie, a 68 wyższe. Wiedza bezdomnych nie pochodzi zresztą tylko z ukończonych szkół, ale została również nabyta w procesie socjalizacji umiejętności i zasobów, a także podczas warsztatów i rozmów podejmowanych w schronisku. Charakterystyczne jednak dla tej grupy społecznej jest niestosowanie posiadanej/pozyskanej wiedzy w praktyce.

Świadomość mają, większość z tych osób miała rodziny, pracowała, ma świadomość tego, jak wygląda zdrowy styl życia, ale [...] ich oczekiwania wobec świata i siebie są minimalizowane, także te związane ze zdrowym stylem życia (wywiad nr 2, pracownik schroniska).

Na pewno wiedzą [o zdrowym stylu życia], zwłaszcza jeśli chodzi o odżywianie. Są świadomi, ale nie podejmują aktywności, nie dbają o higienę (wywiad nr 7, pracownik schroniska).

To nie wiedza jest głównym, a tym bardziej jedynym motywatorem do zmian zachowań, a szereg czynników, które wpływają na sposób myślenia bezdomnego o sobie i swoim miejscu w społeczeństwie, na jego motywację do działania oraz wiarę w możliwość osiągnięcia założonego celu. Bez poznania i zrozumienia całego kontekstu społecznego, w którym zanurzona jest jednostka, podejmowanie działań z zakresu promocji zdrowia wydaje się skazane na porażkę. Zdrowie nie jest głównym priorytetem działań bezdomnego. Koncentruje się on raczej na najbardziej podstawowych potrzebach związanych z zaspokojeniem głodu, bezpiecznym noclegiem, ogrzaniem się. Głównym zaś kierunkiem myślenia jest sytuacja 


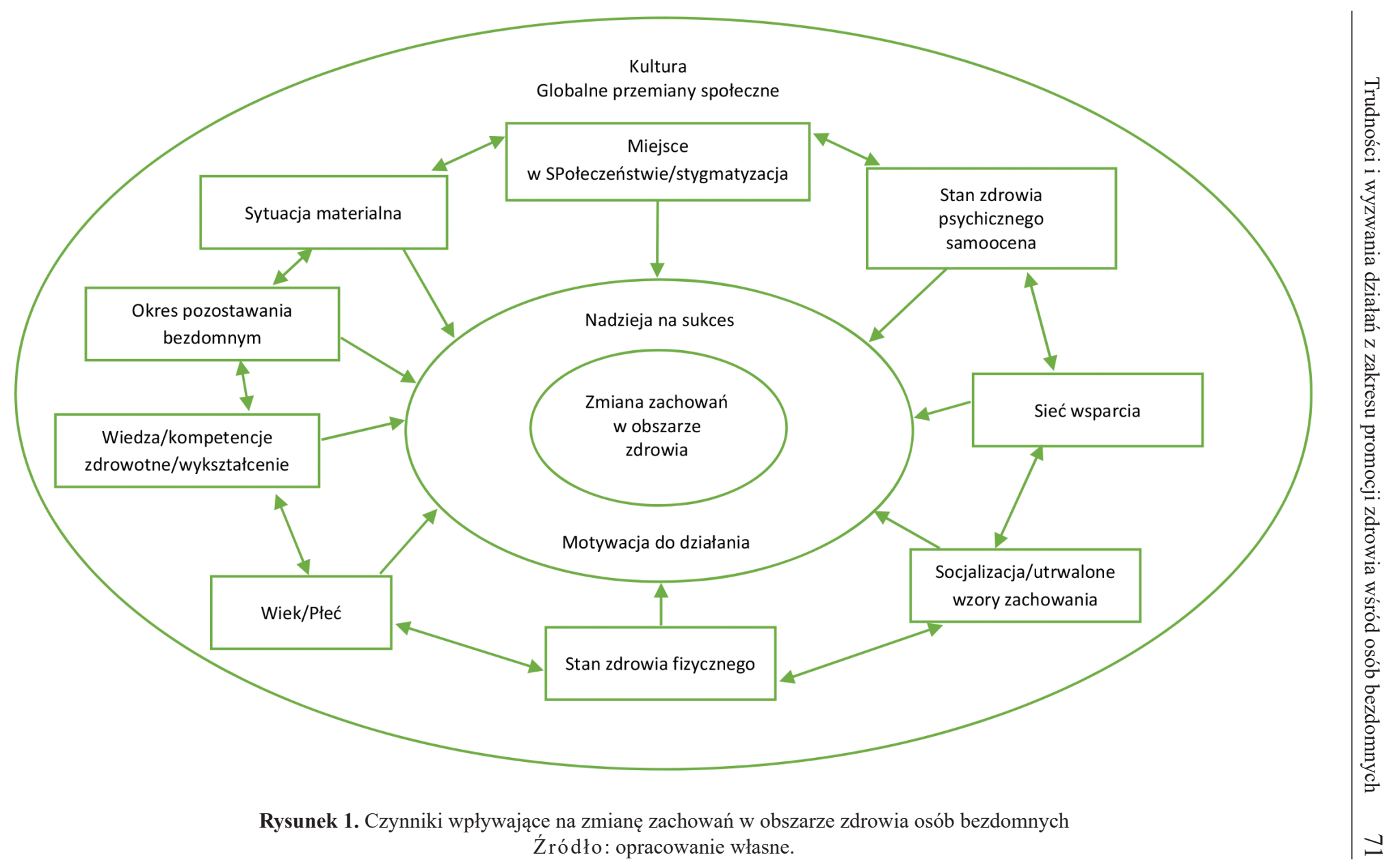


życiowa, w której się znalazł, brak pracy i własnego mieszkania, a nie kondycja zdrowotna. Przestrzeganie reguł zdrowego stylu życia związane z wypełnianiem szeregu zaleceń dotyczących diety, aktywności, używek, higieny, które obiecują w niedookreślonej perspektywie czasowej dobry stan zdrowia oraz wydłużenie życia, dla osoby bezdomnej staje się bardzo abstrakcyjnym, zupełnie nieatrakcyjnym celem. Drugim problemem jest brak motywacji do jakichkolwiek zmian i wiary w powodzenie. Te zaś uzależnione są od szeregu czynników, począwszy od zmiennych demograficznych przez stan zdrowia do aspektów społecznych. Analiza sytuacji osób bezdomnych przebywających w schroniskach wykazała, że zwłaszcza zmienne płci i wieku mocno wpływały na motywację jednostki do zmiany zachowań.

Kobiety lepiej sobie radzą. Jest to związane z tym, że są potencjalnymi matkami oraz że od dziewczynek w procesie wychowania więcej się wymaga m.in. prac domowych. Mężczyźni generalnie gorzej sobie radzą. Są mniej zdyscyplinowani [...]. Mężczyźni bardziej sobie odpuszczają, mają mniejszy napęd na to, by być postrzegani w sposób dobry, jako schludni, czyści, w porządku do siebie i świata. Kobiety mają większą potrzebę postrzegania siebie w kategoriach bycia w porządku, co przekłada się na kontakt ze społeczeństwem, załatwianie różnych spraw w urzędach czy bycie w ogóle odbieranym przez innych (wywiad nr 3, pracownik schroniska).

Samotne, starsze są w gorszej sytuacji, mają mniejszą motywację i chęci. Młodsze czekają często na lokal i ten czas wykorzystują na uporządkowanie swoich kwestii, mają na co czekać. Starsze i samotne widzą tylko w perspektywie kolejny ośrodek (wywiad nr 11, pracownik schroniska).

Jak kobieta trafiała do nas z dziećmi, to ona starała się jak najszybciej od nas uciec [...] w takim sensie, by być jak najkrócej w schronisku. One potrafiły starać się o pracę, o mieszkanie. [...] często starały się tych mężów, którzy bili i pili, z mieszkania wyrzucić i wrócić do domu, ale już były tam bezpieczne. Mężczyźni nie są tak przedsiębiorczy i zaradni. Im nie zależy. Kobietom zależy, zwłaszcza tym, które mają dzieci (wywiad nr 9, pracownik schroniska).

Kobiety, zwłaszcza młode, najlepiej rokują, jeśli chodzi o szanse wyjścia $\mathrm{z}$ bezdomności. Związane jest to z kondycją zdrowotną, podstawowymi umiejętnościami społecznymi czy dbaniem o swój wizerunek. Macierzyństwo dodatkowo motywuje je do zmiany swojej sytuacji życiowej. Trzeba w tym miejscu zaznaczyć, że kobiety, które mają dzieci, jednocześnie mają większe szanse i możliwości na wyjście z bezdomności, ponieważ szybciej otrzymają wsparcie instytucjonalne w postaci chociażby lokalu socjalnego niż samotna, starsza i schorowana kobieta. Nie chroni ich to jednak przed doświadczeniem niewydolności systemu pomocy społecznej związanej z opieszałością i zbiurokratyzowaniem. Bezdomni przez lata czekają na załatwienie spraw urzędowych, takich jak rozwód czy otrzymanie mieszkania socjalnego. Jednocześnie przez ten czas nie mogą pracować w pełnym wymiarze. Tym samym wciąż wegetują w schronisku. Im dłużej zaś trwa taka sytuacja, tym trudniej jest im odnaleźć się w rzeczywistości, a także odzyskać pewność siebie i poczucie własnej wartości. Wśród respondentów 
biorących udział w badaniu 39\% doświadczało bezdomności minimum 5 lat (w tym $13 \%$ ponad 10 lat), zaś $32 \%$ pytanych - od 2 do 4 lat.

Silnym faktorem motywacji do działania, dającym nadzieję na sukces, okazuje się stan zdrowia fizycznego. W ostatnich latach w schroniskach obserwuje się wzrost odsetka bezdomnych w podeszłym wieku, schorowanych i niepełnosprawnych.

Trafiają do nas starsi ludzie, porzuceni przez rodzinę. Mamy mnóstwo tutaj osób, które są niepełnosprawne, wracają do nas po szpitalach, bo rodziny nie mają ochoty, nie chcą, nie mają warunków, nie mają możliwości, by się nimi zająć. Są to najczęściej osoby leżące po różnego rodzajach amputacjach, z różnymi skrzywieniami psychicznymi [...]. Jest więcej chorych niepełnosprawnych. Powiem tak, około $60-70 \%$ naszych podopiecznych to są osoby chore, niepełnosprawne. My tak naprawdę robimy się ośrodkami dla osób niepełnosprawnych (wywiad nr 1, pracownik schroniska).

Więcej jest osób, które są niepełnosprawne ruchowo, jest coraz więcej osób, które są chore przewlekle (wywiad nr 2, pracownik schroniska).

$\mathrm{Na}$ przestrzeni tych lat jest dużo więcej kobiet, które są już w tym podeszłym wieku, około 60-letnich, które są bezdomne, ale które także zmagają się z wieloma chorobami i nie mają szans na wyjście już z tej bezdomności (wywiad nr 3, pracownik schroniska).

Są osoby, które deklarują niemożność wyjścia z sytuacji, które są schorowane, kompletnie nie mają szans na znalezienie pracy, jedyne, co mogą zrobić, to czekać na DPS. Takich osób jest dość dużo (wywiad nr 8, pracownik schroniska).

Jest tu pani, która jest w trudnym stanie zdrowotnym i najlepiej byłoby, gdyby miała możliwość pójścia do domu pomocy społecznej, ale dwukrotnie dostała już odmowę, że jej stan zdrowia jej nie kwalifikuje, a ona nie może liczyć na nic innego, więc albo zostanie tutaj do końca życia, albo w końcu uda się, by poszła do domu pomocy społecznej, gdzie po prostu miałaby lepsze zabezpieczenie zdrowotne (wywiad nr 6, pracownik schroniska).

Dla wielu respondentów powrót do samodzielnego życia jest niemożliwy. Jedyna perspektywa, jaka ich czeka, to zmiana jednego ośrodka na inny: ze schroniska dla bezdomnych na dom pomocy społecznej. Położenie, w jakim się znaleźli, i brak możliwości wyjścia z tej sytuacji w sposób niezwykle wyraźny wpływają na ich stan zdrowia psychicznego i demotywują do jakiejkolwiek troski o własne zdrowie. Niepokojące jest również to, że wielu z nich posiada żyjących krewnych, rodziny, które odmawiają im jednak wsparcia, nie wywiązują się z funkcji opiekuńczo-pielęgnacyjnych. 33\% respondentów biorących udział w badaniu zadeklarowało, że ma bliską rodzinę, z którą nie utrzymuje kontaktów. Niemalże taki sam odsetek złożył podobną deklarację w stosunku do dalszych krewnych. Co zaskakujące, $41 \%$ badanych wskazało, że ma bliską rodzinę (rodziców, rodzeństwo, dziadków, dzieci), z którą utrzymuje kontakt, a jednak zmuszone jest egzystować w schronisku dla bezdomnych. $43 \%$ pytanych przyznało zaś, że w nagłym problemie, takim jak wypadek czy choroba, mogą liczyć tylko na siebie. Odrzucenie, izolacja społeczna, brak wsparcia nie dotyczą tylko rodziny i bliskich znajomych. Bezdomni mają bardzo silne poczucie stygmatyzacji społecznej. 
Myślę, że bezdomność bierze się z tego, że jesteśmy teraz takim społeczeństwem zatomizowanym, w tym momencie przy tych ludziach zabrakło kogoś, kto podałby im rękę, stąd się wzięło, że zaczęli pić, jak zaczęli pić, to się porozpadały rodziny, utracili pracę, pojawił się konflikt z prawem. [...] bezdomność bierze się stąd, że upadają takie wartości jak rodzina, że ta rodzina nie jest w stanie zaopiekować się wszystkimi swoimi członkami (wywiad nr 2, pracownik schroniska).

Mamy taką ogólną tendencję społeczną, by izolować osoby nieradzące sobie psychicznie i z tym, że nasza populacja zmierza w tym kierunku narcystycznym, gdzie słabość, lęki, gdzie wyrażenie emocji są niezbyt dobrze widziane, a jak już ktoś sobie nie radzi, jest poza systemem, to natychmiast jest odsuwany od reszty świata. [...] reszta społeczeństwa nie chce mieć nic wspólnego z ludźmi bezdomnymi, słabymi, wykluczonymi, z ludźmi potrzebującymi pomocy i niestety społeczeństwo hardzieje zamiast się zmiękczać, więc ci ludzie mają mniejsze też szanse na wsparcie (wywiad nr 5, pracownik schroniska).

Widać dynamikę bezdomni - społeczeństwo. A mianowicie tak to wygląda, że społeczeństwo utrzymuje tych ludzi w bezdomności. Nawet gdyby chcieli wyjść z bezdomności, myśleć o tym, zastanawiać się, zmieniać swoją postawę, szczególnie na początku tej drogi, to, z czym się spotykają, to opór i dołowanie (wywiad nr 10, pracownik schroniska).

Generalnie to jest tak, że oni [bezdomni] często spotykali się z nieprzychylnością służby zdrowia i nie chcą się leczyć. Mówię tu już o takich chorobach nie psychicznych, ale o podłożu typowo medycznym, ale nie chcą się leczyć ani chodzić do lekarza. [...] Bo personel medyczny daje im ciągle do zrozumienia, że są gorsi. Nie lubią szpitali ani lekarzy (wywiad nr 8 , pracownik schroniska).

A kogo tam obchodzi bezdomny, w szpitalu odnoszą się do mnie jak do psa, patrzą na mnie jak na psa - takie teksty można usłyszeć (wywiad $\mathrm{nr} 4$, pracownik schroniska).

Większość z nich wie, że społeczeństwo traktuje ich gorzej jak zwierzęta. Bo nad zwierzętami wszyscy się litują, a osoby bezdomne są uważane za osoby, które są niepotrzebne, są darmozjadami (wywiad $\mathrm{nr} 7$, pracownik schroniska).

Oni czują się tak naznaczeni społecznie, że są bezdomni, że są obywatelami drugiej kategorii, że są niepotrzebni, że już nie chcą wychodzić na zewnątrz. Nie chcą wracać do społeczeństwa, bo boją się, że będzie im to ciążyło, będzie się za nimi ciągnęło. To są rzeczy, które oni ukrywają (wywiad nr 12, pracownik schroniska).

Analizując współczesne przyczyny bezdomności, coraz trudniej broni się dziś spojrzenie na to zjawisko z punktu widzenia Mertonowskiej anomii, jako wyraz buntu, indywidualizmu czy nonkonformizmu (Merton 2002). Bezdomność coraz rzadziej staje się wolnym wyborem jednostki, która decydując się na tułaczy tryb życia, demonstruje swoje niezadowolenie i brak akceptacji dla zasad obowiązujących w danym społeczeństwie. Bardziej zasadne w rozumieniu relacji pomiędzy społeczeństwem a bezdomnymi wydaje się sięgnięcie do teorii stygmatyzacji Goffmana czy teorii etykietowania i związanego z nią Beckera (2018). Goffman wprowadził do swojej teorii pojęcia tzw. tożsamości oczekiwanej i rzeczywistej. Społeczna oczekiwana tożsamość dotyczy wszystkiego tego, czego wymagamy od jednostki. Z punktu widzenia społeczeństwa bezdomni zawiedli 
te oczekiwania. Ich tożsamość rzeczywista wyraźnie różni się od tej, której spodziewałoby się i akceptowało społeczeństwo. Ta inność prowadzi do potępienia, odrzucenia i izolowania tych, którzy nie wpisują się w oczekiwania społeczne. Goffman zwrócił uwagę na trzy rodzaje stygmatów: związane z ułomnością ciała, z wadami charakteru oraz z przynależnością, czyli tzw. stygmat plemienny. Wydaje się, że bezdomność wpisuje się w pewnym sensie we wszystkie Goffmanowskie stygmaty. Co więcej, bezdomni noszą w sobie jednocześnie tzw. właściwości zdyskredytowane i dyskredytujące, tj. zarówno takie, które są od razu widoczne dla otoczenia (np. nieprzyjemny zapach, brak higieny, widoczne oznaki choroby, woń alkoholu), jak i takie, co do których jednostka zakłada, że otoczenie w danej chwili nic nie wie (np. brak mieszkania, brak pracy) (Goffman 2005; Goffman 2006; Goffman 1981). Mank off (1971) kontynuując myśl Goffmana, zwrócił uwagę, że stygmat nie zawsze musi wynikać z określonego zachowania, ale $\mathrm{z}$ faktu bycia innym. Według niego jest to tzw. dewiacja przypisana, kiedy status dewianta uzyskuje się niezależnie od działania czy intencji. Bezdomny nie zawsze jest alkoholikiem czy przestępcą. Do schronisk trafia coraz więcej podopiecznych uciekających przed przemocą domową lub schorowanych. Tymczasem w oczach społeczeństwa bezdomność ma tylko jedno - negatywne - oblicze. Taki uproszczony mechanizm rozumienia i oceniania bezdomnych związany jest z tzw. stereotypami dewiacyjnymi. Konsekwencjami stosowania stereotypów dewiacyjnych jest, po pierwsze, traktowanie ich jako rzeczywistych zestawów cech lub zachowań dewiantów, po drugie, oczekiwanie od dewiantów złego zachowania i interpretowanie wszelkich sytuacji niejednoznacznych na ich niekorzyść, po trzecie, odrzucanie i izolowanie wszystkich jednostek, które odpowiadają przyjętym stereotypom (Nowakowska 2008). Tym samym społeczeństwo naznacza jednostki, etykietuje je. Jak zaznacza Becker,

o tym, że ktoś zostanie [w oczach społeczeństwa - KPS] dewiantem, nie decyduje zachowanie dewiacyjne. Działają tu procesy niezwiązane z samym zachowaniem, które mają ogromny wpływ na to, czy dana osoba otrzyma etykietę dewianta, czy nie. Kluczowe znaczenie dla tego, czy tak się stanie, może mieć ubiór, sposób mówienia lub kraj, z którego jednostka pochodzi (Giddens 2010: 231).

Warto $\mathrm{w}$ końcu podkreślić, że naznaczenie jest ściśle skorelowane z tzw. samonaznaczeniem. Etykietowanie nie tylko wpływa na to, jak społeczeństwo postrzega jednostki, ale także na ich własne poczucie tożsamości. Lemert zwrócił uwagę, że każdy członek społeczeństwa narusza jakieś przyjęte normy czy wartości (dewiacja pierwotna), ale dopiero kiedy jednostka otrzymuje etykietę dewianta i przyjmuje ją, etykieta staje się podstawą jego tożsamości i przyczynia do utrwalenia zachowań dewiacyjnych (dewiacja wtórna). Etykieta nadaje takiej jednostce nową, dewiacyjną pozycję społeczną lub tożsamość, przekreślając dotychczasową (Lemert 1972). Co więcej, dla osoby, „która otrzymała etykietę, niefortunną konsekwencją jest fakt, że piętno zaczyna dominować w postrzeganiu 
tej osoby przez innych. Kimkolwiek by ona nie była (np. ojcem, rzemieślnikiem itp.), traktuje się ją przede wszystkim jak dewianta" (Sokołowska 1986: 211-213), zaś ,jego dotychczasowa tożsamość czerpana z poczucia przynależności do społeczeństwa, różnych grup w jego ramach, zajmowania różnych pozycji i pełnienia różnych ról ulega destrukcji. Pojawia się w to miejsce tożsamość człowieka marginesu, wygnańca, outsidera" (Sztompka 2002: 412). Nadana etykieta odzwierciedla się w jaźni naznaczonego jako autodefinicja odrzuconego, co prowadzi do spadku samooceny, poczucia odrzucenia, bycia gorszym czy wręcz bezsensu dalszej egzystencji. Tym samym wyizolowanie bezdomnych dotyczy dwóch niezależnych sfer, które na siebie oddziałują, tj. odrzucenia ich przez otoczenie oraz samoizolowania się (Piekut-Brodzka 2006).

Przez to, że są naznaczeni, mają niską samoocenę. Czują się ograbieni ze swojego człowieczeństwa. Ukrywają się. Jak jest np. telewizja i coś kręci, to oni unikają tego, nie chcą, by ktoś ich tam widział, że są bezdomni. Trudno jest w dzisiejszych czasach, nastawionych na sukces, być człowiekiem marginesu, ze schroniska, któremu coś nie wyszło. Mają bardzo niską samoocenę i też się w tym sami utwierdzają (wywiad nr 4, pracownik schroniska).

Większość ma zaniżoną samoocenę. [...] Większość na samym wstępie ma niską samoocenę ze względu na wcześniejszą sytuację, brak wsparcia w rodzinie, przemocowe kwestie i weszła do schroniska już z niską samooceną. [...] poczucie bycia bezdomnymi, to, jak są postrzegane [...], sprawia, że czują się gorsze (wywiad nr 8, pracownik schroniska).

Poczucie wyobcowania czy zaburzenia własnej wartości towarzyszy bezdomnym na długo przed trafieniem do schronisk (Olech, Ługowski 2006). Swój początek w wielu przypadkach ma w niewłaściwym procesie socjalizacyjnym, wychowywaniu się w rodzinie z problemem alkoholowym lub przemocy. Część bezdomnych dorastała w rodzinie tzw. zimnego chowu, gdzie opiekunowie byli wydolni „technicznie”, ale zabrakło wsparcia emocjonalnego i budowania poczucia własnej wartości. Niewłaściwe wzorce wychowawcze są nierzadko powielane na zasadzie „błędnego koła” poprzez nieodpowiedni dobór partnera lub uciekanie przed problemami w alkohol. Dziedziczone są nie tylko zachowania antyzdrowotne, ale także niskie standardy moralne (popadanie w konflikt z prawem) oraz wyuczona bezradność i niegospodarność, sprzyjająca problemom finansowym. Z kolei brak wsparcia prowadzi do poczucia osamotnienia, wyobcowania i niskiej samooceny, a także łatwiejszego poddawania się kryzysom. Tego typu osoby szybciej odczuwają bezradność i borykają się z nieumiejętnością radzenia sobie w życiu. Przebywanie w schronisku potęguje ten stan rzeczy. Co więcej, $\mathrm{z}$ danych pochodzących z polskich badań nad bezdomnością wynika, że poziom zdrowia psychicznego jest niższy u osób mieszkających w schroniskach niż u bezdomnych funkcjonujących poza nimi (Dębski 2008). Autorzy tłumaczą taką zależność specyfiką funkcjonowania tego typu instytucji, gdzie podopieczni muszą przestrzegać określonych zasad, są pozbawieni intymności i często przebywają w przeludnionych pomieszczeniach, co nierzadko prowadzi do konfliktów. 
Przeprowadzone wśród respondentów testy psychologiczne przy użyciu m.in. Kwestionariusza Nadziei na Sukces, a także Skali Samooceny Rosenberga wskazały, że badani są bardzo krytyczni wobec siebie, a także nisko oceniają swoje możliwości. Mają poczucie porażki związanej z utratą domu, pracy, koniecznością przebywania w schronisku, która przekłada się na ich poczucie wartości. Nie wierzą również w pozytywne efekty swoich działań i możliwość odniesienia sukcesu. Tym samym większość bezdomnych nie stawia sobie wyzwań i nie obiera celów. Tym bardziej nie dostrzega takiej potrzeby w obszarze zdrowia.

Pobyt w schronisku demoralizuje. [...] Ci, co tu zakotwiczyli na dłużej, to z nimi jest trudniej, bo oni przyzwyczaili się do tego, że mogą nic nie robić. [...] Oni nic nie muszą, nic nie potrzebują. Może to taka choroba, że człowiek będąc tutaj [w schronisku], sam się degeneruje. Jeść dostanie, ma gdzie spać i tak życie płynie (wywiad nr 1, pracownik schroniska).

Oni uważają, że mogą jeść niezdrowe jedzenie, pić niezdrowe alkohole, bo te potrzeby są zupełnie inne, mają inne cele. Jeśli alkohol ma nie prowadzić do zabawy, tylko do ucieczki, to on nie musi być dobrej jakości (wywiad nr 2, pracownik schroniska).

To jest też związane z ograniczeniem własnych potrzeb. Jeśli ktoś przyzwyczai się do mieszkania z obcymi osobami, ma jakieś tam trzy posiłki dziennie, że ma coś wykonać, co ma zlecone, to nie chcą niczego więcej. Ograniczyli swoje potrzeby do minimum tego, co oferuje i oczekuje od nich schronisko (wywiad $\mathrm{nr} 7$, pracownik schroniska).

Jeśli chodzi o papierosy, to przeważająca ilość pań jest uzależniona i pali i jest to bardzo powszechne. Myślę, że tego nie postrzegają jako jakiś problem, tylko po prostu palą (wywiad nr 5, pracownik schroniska).

Co do papierosów, to gorzej. Mają świadomość, że to im szkodzi, ale wychodzą z założenia, że wiele rzeczy szkodzi, a to im jeszcze dodatkowo pomaga [rozładowuje stres] (wywiad nr 3, pracownik schroniska).

Dbanie o aktywność fizyczną czy prawidłowe odżywianie nie jest bezpośrednio związane z możliwością wyjścia z bezdomności, a więc nie jest dla bezdomnych priorytetem. Co więcej, sytuacja, w jakiej się znajdują, i subiektywna krytyczna ocena szansy zmiany swojego położenia sprawia, że bezdomni ograniczają swoje potrzeby oraz oczekiwania względem siebie. Zachowania zaś, które z medycznego punktu widzenia będą postrzegane jako niewłaściwe, tj. palenie tytoniu, spożywanie alkoholu, sięganie po narkotyki, stosowanie nadmiernej ilości środków nasennych i przeciwbólowych itp., będą służyły do ucieczki i rozładowania stresu. Paradoksalnie jednocześnie będą przyczyniały się, na zasadzie błędnego koła, do dalszej degradacji zdrowia fizycznego i psychicznego, pogłębiania uzależnień oraz utrudniały zmianę sytuacji. 


\section{Konkluzje}

Bezdomność jest takim kryzysem w życiu człowieka, który bardzo silnie wpływa na działanie jednostki we wszystkich wymiarach zdrowia, na jej codzienne wybory i hierarchię potrzeb. Walka o przetrwanie i konieczność zaspokojenia podstawowych potrzeb wyklucza koncentrowanie się na własnym zdrowiu i dbanie o jego dobry stan, a wręcz nierzadko sprzyja jego pogorszeniu. Zdrowie dla osób wykluczonych przestało być wartością i wyznacznikiem działania. Tym samym ani programy społeczne promujące prozdrowotny styl życia, ani nawet dostarczana wiedza w tym zakresie nie są w stanie zmienić nastawienia czy sposobu myślenia bezdomnych o własnym zdrowiu i sprawności. Problem stanu zdrowia osób bezdomnych i przyjętego przez nie stylu życia najdobitniej pokazuje, że promocja zdrowia nie może ograniczyć się tylko do chwytliwych medialnych haseł czy prostych wskazówek, jak zdrowo żyć. Wymaga uwzględnienia szeregu różnych zmiennych, a nade wszystko całego kontekstu społecznego. Zofia Słońska podkreśla, że jednostki nie funkcjonują w próżni społecznej. Sfera behawioralna wpływa na stan zdrowia, ale ta pierwsza jest uwarunkowana przez czynniki środowiskowe (Słońska 2015). Ludzkie zachowania, także te z obszaru zdrowia i choroby, nie mogą być rozpatrywane w oderwaniu od kontekstu społecznego. Tak bowiem jak jednostki tworzą społeczeństwo, tak społeczeństwo kształtuje jednostki i wpływa na ich zachowania oraz wybory (Taylor 2007). Dopiero zrozumienie, jakie czynniki leżą u podstaw wyborów życiowych, co determinuje styl życia danej jednostki czy grupy społecznej, w pełni pozwala wyodrębnić i zrozumieć psychospołeczne uwarunkowania aktywności w obszarze zdrowia oraz przyczyny podejmowania lub też odrzucania określonych zachowań ważnych dla stanu zdrowia człowieka. Tym samym koncepcje promocji zdrowia nieuwzględniające kontekstu społecznego lub też pomniejszające jego znaczenie wydają się skazane na porażkę. Niewątpliwie konieczna jest w tej materii dalsza pogłębiona refleksja, prowadząca do zmian we współczesnych koncepcjach promocji zdrowia.

\section{Bibliografia}

Becker H. (2018), Outsiders. Studies in the Sociology of Deviance, Simon \& Schuster, Nowy Jork. Cianciara D. (2011), Trzy dekady promocji zdrowia - czas działać, „Problemy Higieny i Epidemiologii”, t. 92(1), s. 7-13.

Cockerham W.C., Ritchey F.J. (1997), Dictionary of Medical Sociology, Greenwood Press, Westport-London.

Dębski M. (2008), Kondycja zdrowotna osób bezdomnych, [w:] M. Dębski, S. Retowski (red.), Psychospołeczny profil osób bezdomnych w Trójmieście, Uniwersytet Gdański, Gdańsk.

Giddens A. (2010), Socjologia, przeł. A. Szulżycka, Wydawnictwo Naukowe PWN, Warszawa.

Goffman E. (1981), Człowiek w teatrze życia codziennego, przeł. H. Datner-Śpiewak, P. Śpiewak, Państwowy Instytut Wydawniczy, Warszawa. 
Goffman E. (2005), Piętno. Rozważania o zranionej tożsamości, przeł. A. Dzierżyńska, J. Tokarska-Bakir, Gdańskie Wydawnictwo Psychologiczne, Gdańsk.

Goffman E. (2006), Rytuat interakcyjny, przeł. A. Szulżycka, Wydawnictwo Naukowe PWN, Warszawa.

Grossmann R., Scala K. (1997), Promocja zdrowia a rozwój organizacyjny. Tworzenie siedlisk dla zdrowia, przeł. B. Woynarowska i in., Instytut Matki i Dziecka, Warszawa.

LaLonde M. (1981), A New Perspective on the health of Canadians, Minister of Supply and Services, Ottawa.

Lemert E. (1972), Human Deviance, Social Problems and Social Control, Prentice Hall, Englewood Cliffs.

Łódzki Urząd Wojewódzki w Łodzi (ŁUW) (2019), Rejestr miejsc, w których gminy województwa tódzkiego udzielaja tymczasowego schronienia w schroniskach dla osób bezdomnych, schroniskach dla osób bezdomnych z ustugami opiekuńczymi, noclegowniach oraz ogrzewalniach, http://www.pomoc.lodzkie.eu/page/index.php?str=351 (dostęp: 10.04.2021).

Mankoff M. (1971), Societal reaction and career deviance: A critical analysis, „The Sociological Quaterly", t. 12(2), s. 204-218.

Merton R.K. (2002), Teoria socjologiczna i struktura społeczna, przeł. E. Morawska, J. Wertenstein-Morawski, Wydawnictwo Naukowe PWN, Warszawa.

Miejski Ośrodek Pomocy Społecznej w Łodzi (MOPS) (2019), Podsumowanie badania liczby ludzi bezdomnych - edycja 2019, https://mops.uml.lodz.pl/informacje/podsumowanie-badania-liczby-ludzi-bezdomnych-edycja-2019/(dostęp: 20.03.2021).

Ministerstwo Rodziny i Polityki Społecznej (MRiPS) (2019), Wyniki ogólnopolskiego badania liczby osób bezdomnych - edycja 2019, https:/www.gov.pl/web/rodzina/wynikiogolnopolskiego-badania-liczby-osob-bezdomnych-edycja-2019 (dostęp: 29.03.2021).

Nowakowska A. (2008), Społeczne postrzeganie bezdomności. Zjawisko stereotypizacji, [w:] M. Dębski, K. Stachura (red.), Oblicza bezdomności, Uniwersytet Gdański, Gdańsk.

Olech P., Ługowski K. (2006), Problematyka zdrowia osób bezdomnych - perspektywa specjalistów pomocy społecznej i stużby zdrowia, [w:] E. Bełdowska, E. Szczypior, M. Dębski, Ł. Browarczyk, P. Olech, K. Ługowski (red.), Kompendium bezdomność a zdrowie, „Pomost. Pismo Samopomocy”, Regionalne Centrum Informacji i Wspomagania Organizacji Pozarządowych, Gdańsk.

Ostrowska A. (1999), Styl życia a zdrowie. Z zagadnień promocji zdrowia, Wydawnictwo Instytutu Filozofii i Socjologii PAN, Warszawa.

Piekut-Brodzka D.M. (2006), Bezdomność, Chrześcijańska Akademia Teologiczna, Warszawa.

Piekut-Brodzka D.M. (2013), Bezdomność na Mazowszu. Raport z badania, Instytut Pracy i Spraw Socjalnych, Warszawa.

Puchalski K. (2008), Uwarunkowania aktywności zdrowotnej w kontekście promocji zdrowia - szkic socjologicznego modelu, [w:] I. Heszen, J. Życińska (red.), Psychologia zdrowia w poszukiwaniu pozytywnych inspiracji, Wydawnictwo Szkoły Wyższej Psychologii Społecznej Academica, Warszawa, s. 205-222.

Sadowski Z. (1994), Promocja zdrowia - szansa i konieczność, „Promocja zdrowia. Nauki Społeczne i Medycyna", nr 3-4, s. 13-35.

Skrzypek M., Marzec A. (2018), Spoleczna perspektywa interpretacyjna w promocji zdrowia i zdrowiu publicznym, „Hygeia Public Health”, t. 53(3), s. 232-240.

Słońska Z. (2015), Wkład polskiej socjologii w rozwój promocji zdrowia. Od socjologii medycyny do socjologii w promocji zdrowia, [w:] A. Ostrowska, M. Skrzypek (red.), Socjologia medycyny w Polsce z perspektywy pólwiecza. Nurty badawcze, najważniejsze osiagnięcia, perspektywy rozwoju, Wydawnictwo Instytutu Filozofii i Socjologii PAN, Warszawa. 
Sokołowska M. (1986), Socjologia medycyny, Państwowy Zakład Wydawnictw Lekarskich, Warszawa.

Sztompka P. (2002), Socjologia. Analiza społeczeństwa, Wydawnictwo Znak, Kraków.

Taylor S. (2007), Sociology, Social Research and Health, [w:] S. Taylor, D. Field (red.), Sociology of Health and Health Care, Blackwell Publishing, Oxford, s. 3-24.

\title{
DIFFICULTIES AND CHALLENGES OF HEALTH PROMOTION ACTIVITIES AMONG HOMELESS PEOPLE
}

\begin{abstract}
Homelessness is the kind of crisis in a person's life that has a very strong impact on the individual's actions in all dimensions of health, on his daily choices and on the hierarchy of needs. The struggle for survival and the need to meet basic needs excludes focusing on one's own health and taking care of its good condition, and even often promotes its deterioration. The problem of the health of homeless people and the lifestyle they have adopted most clearly shows that health promotion must not be limited to catchy media slogans or simple tips on how to live a healthy life. It requires taking into account a number of different variables and, above all, the whole social context.

The aim of the prepared article is to try to answer the question of the possibility and effectiveness of health promotion activities among excluded groups, for example among homeless people. On the basis of his own research conducted among homeless people in the shelters in city of Łódź and among employees of these institutions, the author tries to answer the question of what is the state of knowledge of homeless people about the health-promoting lifestyle, what health-related behaviors are characteristic for this group, but above all what factors influence lifestyle, including health choices, and shape the health of marginalized people.
\end{abstract}

Keywords: homeless people, health promotion, lifestyle, health. 